\title{
MICROBIOLOGICAL EVALUATION OF HYDRIC RESOURCES PROVIDED BY THE TIETÊ RIVER, DISTRICT OF VITORIANA, BOTUCATU, SP, BRAZIL
}

\section{T.A.F. Corrêa ${ }^{1}$, V.L.M. Rall ${ }^{1}$, M.G. Silva ${ }^{2}$, C.A.M. Lopes ${ }^{1}$}

${ }^{1}$ Universidade Estadual Paulista, Instituto de Biociências, Departamento de Microbiologia e Imunologia, CP 510, CEP 18618-000, Botucatu, SP, Brasil.

\begin{abstract}
Water, fundamental to the existence of mankind, demands the attention of competent authorities since its contamination could become a vehicle for transmission of infectious diseases. Thus the present work aimed to investigate the presence of fecal and total coliforms in water samples taken from wells, a lake and both the margin and channel of the Tiete River, Barra Bonita Dam, Botucatu, São Paulo, Brazil. The necessity of investigation arose by virtue of a high gastrenteritis index detected in the population that utilizes these hydric resources. The most probable number (MPN) of fecal and total coliforms was determined for 168 water samples through the method of multiple tubes. The results showed that only $42 \%$ of the samples collected in 4 wells investigated were considered of good quality for human consumption, by not presenting fecal coliforms in $100 \mathrm{~mL}$ of water, according to Decree $N^{\circ} 518$ de 25/103/2004. Regarding suitability for bathing/recreational use, according to CONAMA Resolution 357 of 17/03/2005, it was observed that in the locations investigated, only $10 \%$ of the samples analyzed were considered inappropriate for bathing and $90 \%$ of the remainder were considered satisfactory.
\end{abstract}

KEY WORDS: Fecal and total coliform, hydric resources, Tiete River.

\section{RESUMO}

AVALIAÇÃOMICROBIOLÓGICA DOSRECURSOSHÍDRICOSPROVENIENTESDORIOTIETÊ, DISTRITODE VITORIANA, BOTUCATU,SP. Aágua constitui um dos elementos fundamentais para a existência do homem e sua preservação é uma necessidade que exige atenção das autoridades competentes, pois sua contaminação pode torná-la um veículo na transmissão de doenças infecciosas. Assim, objetivou-se investigar a presença de coliformes totais e fecais em amostras de água provenientes de poços e lago no Bairro Recreio Jardim Mina de Botucatu, São Paulo, e na margem e meio do canal do Rio Tietê, Represa da Barra Bonita, próxima da Usina da Barra Bonita, Botucatu, São Paulo. A necessidade de investigação ocorreu em virtude do alto índice de gastrenterites detectado na população que utilizam esses recursos hídricos. Foi analisado o Número Mais Provável (NMP) de Coliformes Totais e Fecais em 168 amostras de água através do método de tubos múltiplos. De acordo com resultados, verificou-se que, somente $42 \%$ das amostras coletadas nos 4 poços investigados, foram consideradas de boa qualidade para o consumo humano, considerando este parâmetro, por não apresentarem coliformes fecais em $100 \mathrm{~mL}$ de água, segundo a Portaria MS 518 de 25/103/2004. Quanto aos Padrões de Balneabilidade, segundo a Resolução 357 do CONAMA de $17 / 03 / 2005$, pode-se observar que nos locais investigados, somente $10 \%$ das amostras analisadas foram consideradas impróprias para banho e as $90 \%$ restantes foram consideradas satisfatórias.

PALAVRAS-CHAVE: Coliformes totais e fecais, recursos hídricos, Bacia do Rio Tiete.

\section{INTRODUCTION}

The preservation of water quality is a universal necessity that demands attention on the part of sanitation authorities and agencies, particularly with regard to water sources and water for human consumption, inasmuch as their contamination by human and animal excrement can become a vehicle for transmission of infectious and parasitic diseases. The freshwater volume available for consumption by the world population is $0.8 \%$, while the fraction contaminated by microorganisms is unknown. According to the World Health Organization, $80 \%$ of diseases that occur in the developing world are

${ }^{2}$ Universidade Estadual Paulista, Faculdade de Medicina, Departamento de Patologia, Botucatu, SP, Brasil. 
caused by contamination of water (VALENTE et al., 1999).

Diseases related to water are classified as those of hydric transmission (which act as a vehicle for an infectious agent), and those of hydric origin, caused by determined organic or inorganic chemical substances, present in water at inadequate concentrations, generally higher than standard specifications for water for human consumption (FooD and Drug Adminidtration, 1998).

The Tiete River is the most traditional of the State of São Paulo, not only for crossing São Paulo City, but practically, the whole territory from costal mountain range to the Paraná River and going toward the west of the state. The great drop in altitude along its course (almost $860 \mathrm{~m}$ ) has been used to advantage through the construction of several dams with hydroelectric plants. The length of the river (total 1.15 thousand $\mathrm{km}$ ) has been divided in 4 parts, Upper, Middle (upper and lower) and Lower Tietê. The sampling area in the present study was located in the Middle Tietê (lower) that locates the sampling area determined in this study, which comprises several important cities as Americana, Araraquara, Bauru, Botucatu, Campinas, Jaú, Limeira, Lins, Piracicaba, Rio Claro and São Carlos. The Tiete River is now navigablein the passage of the Jupia $(40 \mathrm{~km})$, Nova Avanhandava and Barra Dams, forming a continuous stretch of $443 \mathrm{~km}$ in extension already in use and characterizing a navigable waterway with $2.400 \mathrm{~km}$ which goes from Conchas, SP, toSãoSimão, GO, (RededAS ÁGUAs, 2006).

In 1992, the government of São Paulo State created the Program for the Depollution of the Tietê River, under the responsibility of SABESP (Service of Provisioning of theState ofSãoPaulo); however named the "Projeto Tietê" it was restricted to the metropolitan area of São Paulo City, thus excluding the river in its course in theinterior of the state (REDEDAS ÁGUAS,2006).

Thefixed and fluctuating population of thestudied area interacts intensely with the river through fishing, recreation, transport, fish farms, irrigation and with direct discharge of untreated sewer.

This context imposes the necessity of routine exams of the water for qualitative evaluation from a bacteriological perspective, independent of the fact that research on pathogenic microorganisms in water requires long and complex procedures to obtain results (MARtins, 1994; SoARes \& Maia, 1999).

Considering that pathogenic agents areeliminated by feces of sick individuals or carriers and transmitted through the water, the evaluation of microbiological quality is realized principally through research of microorganisms indicative of fecal contamination, which when present in water indicate the occurrence of fecal contamination with the risk of the presence of pathogens (PORTO, 1991).
The objective of the present work was to evaluate the microbiological quality of water from the Tiete River basin and Jardim Mina Botucatu, São Paulo, in relation to standards of drinkability and fitness for bathing/recreational use, realized especially as a function of the occurrence of a high index of diarrhea detected, as much in the fixed population as in fluctuating one that utilize these hydric resources.

\section{MATERIAL AND METHODS}

\section{Area of sampling}

A dam on the Tietê River, located in the District of Victoriana, municipal district of Botucatu, away approximately $250 \mathrm{~km}$ of São Paulo City. That area was projected for recreation, sport and leisure, and has 1,500 houses (masonry or wooden), some of them at riverside and others located up to $1 \mathrm{~km}$ from the river's edge. Water treatment systems are not existent throughout the wholearea, being absent in the houses closest to the river that have wells and septic tanks. Garbage collection from the all of the residences does, however, take place, but only once a week.

\section{Collection of samples}

A total of 168 water samples were collected in vials previously sterilized, from wells (96), a lake (24), riverbank (24) and river channel (24). One sample was collected from each location every 15 days for 12 months. Well samples were collected from spigots after the water had been pumped and stored in collection tanks. Lake samples were collected at a depth of $1 \mathrm{~m}$ and those from the riverbank were taken at a distance $1.5 \mathrm{~m}$ from the shore at a depth of $20 \mathrm{~cm}$. Channel samples were gathered with the aid of a boat $100 \mathrm{~m}$ from the river bank at a depth of approximately $3 \mathrm{~m}$.

All collected samples were sent to the Food Laboratory at the Department of Microbiology and Immunology in the Biosciences Institute of UNESP at Botucatu, under refrigeration, not exceeding a period of 8 hours to initiation of the analysis.

Determination of Most Probable Number of Total Coliforms (TC) and Fecal Coliforms (FC) (American Public Health Association, 1992)

Determination of Most ProbableNumber (MPN) of coliforms was realized utilizing the multiple tubes technique.

For the preliminary test, from each sample there were prepared decimal dilutions. Aliquots of $1 \mathrm{~mL}$ from each dilution were inoculated in 5 tubes 
containing $10 \mathrm{~mL}$ of lauryl sulfate broth with an inverted Durham tube. After incubation at $35 \pm 0.5^{\circ} \mathrm{C}$ for 24 to 48 hours, the positive tubes presented turbid medium and the presence of gas in the interior of the inverted Durham tubes.

For the test to confirm total coliform, three loops were transferred from each positive tube to tubes containing $10 \mathrm{~mL}$ bright green bile lactose broth, which were incubated at $35^{\circ} \mathrm{C} \pm 0.5^{\circ} \mathrm{C}$ for up to 48 hours. Turbid medium and production of gas were observed as confirmation of bacteria in the total coliform group.

To confirm fecal coliform (FC), another 3 loops were transferred from LSB positive tubes to tubes containing $5 \mathrm{~mL}$ Escherichia coli broth with an inverted Durham tube, which was incubated for $24 \mathrm{~h}$ at $44.5 \pm$ $0.2^{\circ} \mathrm{C}$ in a water bath. The result was considered positive when gas production occurred in EC tubes.

A strain of Escherichia coli ATCC $\mathrm{n}^{\circ} 25922$ and a strain of Enterobacter, previously identified, were utilized as positive and negative controls, respectively.

For confirmation of $E$. coli, a growth aliquot was transferred from EC tubes into dishes of McConkey agar, incubated at $35 \pm 2^{\circ} \mathrm{C} / 24$ hours. The characteristic colonies were submitted to the following tests: Indole (+), Metila Red (+), Voges Proskauer (-) and Simmons Citrate (-).

\section{Statistical analysis}

Data referring to the most probable number of fecal and total coliforms in water samples collected at the different locations were submitted to thenonparametric Kruskal-Wallis test. The statistical program was employed with a significance level of $5 \%$.

\section{RESULTS AND DISCUSSION}

A total of 96 water samples were analyzed from four wells, with regard to established potability patterns in Decree No 518 on 25/03/2004 (BRASIL, 2004). It was observed that $57(59.4 \%)$ of these were inappropriate for consumption based on levels of fecal coliform in $100 \mathrm{~mL}$ of water. We could observe that the concentration of this indicator ranged from < 3 to $2.4 \times 10^{2} \mathrm{NMP} / 100 \mathrm{~mL}$ (Table 1 ).

For the 24 samples collected from well $\mathrm{A}$, the presence of fecal coliforms was observed in $11(45.8 \%)$ of them, although at low concentrations of up to 14 NMP/100 mL. Well B was found to be more contaminated, since $18(75 \%)$ of the 24 samples presented fecal coliforms in concentrations up to 2.4 $\times 10^{2} \mathrm{NMP} / 100 \mathrm{~mL}$ (Table 1 ). Wells Cand D presented the same rate of contamination with 14 samples showing fecal coliforms (58.3\%). Septic tanks exist in all of the residences that do not have treated water (approximately 30\%) and are responsible for the contamination of the adjacent areas.

From the middle of the Tiete River channel 24 water samples were collected during the year 2003, at 15-day intervals, and all of these samples were positive for the presence of both total and fecal coliforms, which reached concentrations up to $1.5 \times 10^{3}$ and 4.6 $x 10^{2} \mathrm{MPN} / 100 \mathrm{~mL}$, respectively. At the margin of the same river, all samples were positive for both total and fecal coliforms in concentrations of $4.6 \times 10^{4}$ and 4.6 $x 10^{3} \mathrm{MPN} / 100 \mathrm{~mL}$, respectively. These results were expected due to intense pollution of the margins caused by the users of the locale, while in the middle of the river the contamination is diluted.

The 24 lake samples were contaminated by total coliformsand 23(95.8\%) by fecalcoliforms whichreached concentrations of $2.1 \times 10^{3} \mathrm{MPN} / 100 \mathrm{~mL}$ (Table 1).

For analysis of suitability for bathing/recreational use, the standard taken was Resolution $n^{\circ} 357$, of the National Environmental Council (BRASIL, 2005) dated $17 / 03 / 2005$, which establishes classification of appropriate and inappropriate waters for primarycontact recreation, with this last category subdivided into excellent, very good and satisfactory, depending on the number of fecal coliforms detected.

Table 1 - Minimum and maximum limits for Most Probable Number of Fecal and Total Coliforms from well-water samples, Tiete River (margin and channel) and lake, District of Barra Bonita.

\begin{tabular}{|c|c|c|c|c|c|}
\hline \multirow[t]{2}{*}{ Collection location } & \multirow[t]{2}{*}{ No. of Samples } & \multicolumn{2}{|c|}{ Total coliform (MPN/100mL) } & \multicolumn{2}{|c|}{ Fecal coliform $(\mathrm{MPN} / 100 \mathrm{~mL})$} \\
\hline & & Minimum & Maximum & Minimum & Maximum \\
\hline Well AC & 24 & 0 & 93 & 0 & 14 \\
\hline Well AF & 24 & 0 & $2.8 \times 10^{3}$ & 0 & $2.4 \times 10^{2}$ \\
\hline Well MR & 24 & 0 & $1.5 \times 10^{3}$ & 0 & $1.5 \times 10^{2}$ \\
\hline Well EC & 24 & 0 & $1.1 \times 10^{3}$ & 0 & $1.4 \times 10^{2}$ \\
\hline Channel & 24 & $7.5 \times 10$ & $1.5 \times 10^{3}$ & 4 & $4.6 \times 10^{2}$ \\
\hline Margin & 24 & 20 & $4.6 \times 10^{4}$ & 9 & $4.6 \times 10^{3}$ \\
\hline Lake & 24 & 7 & $4.6 \times 10^{3}$ & 0 & $2.1 \times 10^{3}$ \\
\hline
\end{tabular}

MPN: Most Probable Number per $100 \mathrm{~mL}$ of water. 
Of the 24 samples from the Tiete River channel collected every 15 days, in only 2 of them $(8.3 \%)$ did the number of fecal coliforms exceed $250 \mathrm{MPN} / 100 \mathrm{~mL}$, the maximum limit for water to be considered of adequatequality for bathing standards. Thesesamples were collected in winter and autumn without statistically significant seasonal variation. As to the margin of the same river, three samples $(12.5 \%)$ were classified as water inappropriate for recreation with a concentration up to $4.6 \times 10^{3} \mathrm{MPN} / 100 \mathrm{~mL}$. However, in $50 \%$ of the samples the number of fecal coliforms/ $100 \mathrm{~mL}$ permitted classification of these waters as excellent. The lake was the location that presented the greatest number of samples inappropriate for recreation $\left(16.7 \%\right.$ ) with contamination up to $2.1 \times 10^{3}$ $\mathrm{MPN} /$ fecal coliforms $/ 100 \mathrm{~mL}$ of water (Table 1 ).

Based on these analyzed samples, it can be concluded that the contamination level was similar in all seasons of the year ( $p>0.05)$. This could have occurred because temperatures in Brazil during the period of sample collections did not conform to a decreasing pattern, in this way presenting proximity of this parameter over the four seasons of the year, unlike that of Europe and the United States where seasons are more definite and distinct.

Thus, although most of the water samples utilized for human consumption in the Tiete River region would be considered inappropriate, water for recreation of primary contact can be considered of good quality, permitting the population that frequents the recreational area utilization of the margins for swimming. The riverine residents that do not have treated water can deal with this problem by the appropriate chlorination (200 ppm of chlorine) or boiling of the water $\left(15\right.$ minutes at $\left.100^{\circ} \mathrm{C}\right)$.

\section{ACKNOWLEDGMENTS}

This word was supported Grant ${ }^{\circ}$. FAPESP(Grant $\mathrm{n}^{\circ}$. 01/01845-7) awarded to TAFC, and by Research Pro-Reitoria - UNESP to VLMR.

\section{REFERENCES}

American PublicHealth Association - Standard Methods for the examination for water and wastewater. 18th ed., 1992.

Brasil. Ministério da Saúde. Portaria No 518, de 25 de março de 2004

BRASIL. Ministério do Meio Ambiente. Conselho Nacional do Meio Ambiente - CONAMA Resolução No357, de 17 de março de 2005.

Food and Drug Adminidtration. Bacterial analytical manual. 8th ed. AOAC International, 1998.

Martins, M.T. Água limpia para todos. El Cid Informa, v.22, n.1, p. 19-22, 1994.

PоRTо, R.A.L. Hidrologia ambiental. São Paulo: EDUSP, 1991. v. 3.

Rede DAS ÁGUAs. Disponívelem:<http://www.rededasaguas. org.br/nucleo/projeto_tite.htm>. Accessed on: 18 Jul. 2006.

SoAres, J.B. \& MAIA, A.C. Água: microbiologia e tratamento. Fortaleza: EUFC, 1999.

Valente, J.P., Lopes, C.A.M; Caminhas, A.M.T.; Horácio, A. Bacteriological evaluation of the supplies of the Eldorado Municipality - Vale do Ribeira (SP). Revista do Instituto Adolfo Lutz, v.58, n. 2, p. 9-13, 1999.

Received on $10 / 5 / 2006$ Accepted on 24/7/2006 